\title{
A COMPETENCY-BASED MODEL FOR DEVELOPING HUMAN RESOURCE PROFESSIONALS
}

\author{
Glenn M. McEvoy \\ James C. Hayton \\ Alan P. Warnick \\ Troy V. Mumford \\ Steven H. Hanks \\ Mary Jo Blahna \\ Utah State University
}

This article describes a framework for the design and implementation of a competency-based curriculum for graduate management education. The article also outlines how this model has been implemented at one university in the context of a graduate degree in human resource management. Among the significant challenges discussed are the identification of competencies required for professional success; the identification of the specific traits, knowledge, and skills that combine to create competence; and the creation of a curriculum and the associated assessment tools necessary to promote the acquisition of competencies. Student orientation, student development, and student assessment are discussed.

Keywords: competence; human resource professional; development stages; competency categories; graduate education; student assessment

Traditionally, the role of educators, including management educators, has been viewed as one of dissemination of knowledge to students. Recently, human resource management (HRM) scholars and practitioners have begun to focus more broadly on the definition and development of competencies necessary for successful performance in a professional role. This perspective

JOURNAL OF MANAGEMENT EDUCATION, Vol. 29 No. 3, June 2005 383-402

DOI: $10.1177 / 1052562904267538$

() 2005 Organizational Behavior Teaching Society 
assumes that knowledge is only one of several important dimensions that contribute to professional competence. Competence is defined in terms of configurations of traits, motives, knowledge, and skilled behavior (Boyatzis, Stubbs \& Taylor, 2002; Brockbank, Ulrich \& Beatty, 1999; McClelland, 1973).

A competence-based approach to education has intrinsic benefits for managerial training, including potentially greater relevance-something that graduate-level management education has recently been criticized as lacking (Pfeffer \& Fong, 2002). However, there are several challenges that must be faced that do not typically arise in more traditional, functionally oriented programs of study. These challenges include identifying the relevant competencies and their components, determining how to develop and evaluate these components of competence, and integrating both development and assessment of competencies within the institutional constraints associated with more traditional pedagogical frameworks. Therefore, this article has three objectives: first, to describe the development of a competence-based model for graduate education in HRM; second, to illustrate how the model has been applied in one U.S. university; and third, to highlight the key challenges associated with this alternative approach to curriculum design.

This article makes several contributions to the management education literature. First, although a competence approach is often suggested to be more complete and, by implication, more desirable, actual implementation of such a model is rare. In this article, we provide a description of how the model has been designed and implemented in graduate education. It is hoped that this work will serve as a prototype for competency-based curriculum design and will stimulate further discussion of the merits of this approach.

Second, the concept of competence is frequently defined in broad and ambiguous terms. In the process of operationalizing this construct, we are forced to more clearly delineate what a competency is and how competence can be observed, measured, and developed. Therefore, this article maps the components of professional competence within the field of HRM and suggests operationalizations of the construct. Furthermore, because competence as an HR professional overlaps in many ways with managerial competence, such operationalizations are expected to generalize beyond the profession of HRM.

Third, the competence-based model that we propose highlights those aspects of professional competence that may be developed within the context of a 1- or 2-year graduate degree. By implication, this analysis will also describe those aspects of competence that a graduate education cannot be expected to influence to a significant extent. Furthermore, by defining professional competence in dynamic terms, taking into account professional 
development through the course of time, we are able to understand the place of graduate education within the broader context of professional careers.

Finally, the model raises several interesting challenges for educators. One such challenge is the question of whether the selection of candidates for degree programs can be enhanced by pretesting program applicants for their potential to develop competence rather than purely scholastic aptitude. This and other questions are explored in the conclusion of this article. In the following sections, we describe the concept of competence in greater detail. This is followed by a description of the research that led to the implementation of the competence-based graduate program described here. We then discuss the nature of the implementation itself and conclude with a discussion of the key observations and challenges arising from this process.

\section{Professional Competency}

McClelland (1973) is generally credited with launching the competence movement in psychology. Building on McClelland's work, Spencer and Spencer (1993) defined a competency as "an underlying characteristic of an individual that is causally related to ... superior performance in a job or situation" (p .9). Brockbank et al. (1999) indicated that a competency is "who an individual is and what an individual knows and does" (p. 111). Who a person is consists of motives, traits, and self-concept (Spencer \& Spencer, 1993). Therefore, we define HRM professional competence as what a person is, knows, and does that is causally related to superior performance as an HR professional. This definition has several implications.

First, because competence is defined in terms of several latent characteristics such as motives and traits, we can only infer the existence of competence through observation of behavior. This has significant implications for how assessment and development should take place, as traditional forms of assessment—papers, projects, presentations, and examinations - frequently are not designed to capture the breadth of professional competence and may be inappropriate given the nature of the construct.

Second, although we assume that competence leads to superior performance, the definition of performance remains open (Campbell, 1990). For the present discussion, we assume that superior performance means simply the ability to function in a position within the profession at or above the level expected to retain that position.

Third, traditional HR education has focused almost exclusively on the knowledge component of competence. However, this narrow interpretation of the role of education — that of knowledge dissemination — has been ques- 
tioned. For example, Pfeffer and Fong (2002) argued that business degrees do not seem to predict success in business careers and concluded that one of the reasons is a failure to focus on the development of competencies through clinical or action experiences. Taking a competence-based approach to HR curriculum design involves, first, identifying what competencies are critical to professional performance, and second, addressing if and how motives, traits, and skills can be incorporated into an educational program in addition to specialized HR knowledge.

\section{Competence in HRM}

Several efforts have been made recently to identify the critical competencies needed to be a successful HR practitioner. Most of these studies have been driven by a sense that the traditional roles of HR (e.g., administrative expert or employee advocate) are no longer adequate and that to add value to an organization, HR professionals must assume the role of business or strategic partner and change agent (Ulrich, 1997). Several of these competency studies were published in a special issue of Human Resource Management (Heneman, 1999). For example, Kaufman (1999) reviewed the literature of the development of the fields of industrial relations and HR and concluded that at present, the biggest gaps between what employers want in HR graduates and what they are getting are in the areas of written and oral communication skills, leadership, negotiation skills, knowledge of organizational dynamics, and strategic understanding of HR.

The most widely cited study of HR competencies is the work conducted by Ulrich and colleagues (Brockbank et al., 1999; Ulrich, Brockbank, Yeung, \& Lake, 1995). In the first wave of this research, Ulrich et al. (1995) found that technical HR skills, change agent skills, and knowledge of the business were critical to success for HR professionals. The second wave added the notion that strategic knowledge and skills were critical, including areas such as knowledge of financial management, customer demand, and external competitive threats. In the third wave of surveys, researchers added two more areas of HR competency: culture management and personal credibility.

Reporting on a study of HR professionals at Quantum Corporation, Baill (1999) argued that it was essential that these managers possess consulting and facilitation skills and the ability to use a variety of organization development (OD) frameworks and tools. Summarizing key findings concerning competencies required for success in HRM, Barber (1999) concluded that university HR curricula today should include (a) traditional HR functions, (b) change management and leadership skills (communication, negotiation, 
etc.), and (c) business skills (understand the language of business and be able to function as effective business partners). Furthermore, Barber suggested that the proper role of an educational institution is not to produce graduates fully qualified in each of these three areas but rather to provide a broad-based educational foundation on which professionals continue to build through experience and training.

Mansfield (1996) defined a competency as "a detailed, behaviorally specific description of skills and traits that employees need to be effective in a job" (p. 7). Kochanski and Ruse (1996) proposed four levels (or tiers) of competencies. These include traits such as initiative and results orientation and skills such as influencing, leading and facilitating, analytical thinking, and written communication. The Society for Human Resource Management (SHRM) has also been very active over the years in developing and publishing HR competency models (Lawson \& Limbrick, 1996). In a survey of SHRM members, Schoonover (1998) reported three domains of competence in HRM: core, level-specific, and role-specific competence. Core competencies include personal attributes (e.g., motives, traits, and temperament), leadership and management competencies, and functional HR skills. Levelspecific competencies range from entry-level HR jobs to executive-level HR jobs. Role-specific competencies address role breadth and depth, including specialist, generalist, and strategic competencies.

In summary, the literature suggests that competencies reflect configurations of personal characteristics such as traits and motives, along with knowledge and skills, that are inferred from observable behavior. However, to date, these elements of competencies have been defined in general and often ambiguous terms. This article will attempt to augment our understanding of professional HR competence through more precise delineation of the competencies, their components, their operationalization, and application. We focus on the development of competence in the HR profession. However, it is apparent from the list of traits, motives, knowledge, and skills generated by the research reviewed above that professional competence in HRM is not at all inconsistent with general managerial competence. This is not surprising, and we observe that what is perhaps most unique for HR professionals are the technical knowledge of the profession and more highly refined traits and skills that are supportive of roles such as employee advocacy (Ulrich, 1997). Thus, although the model of professional competence, and the educational program that is based on it, focus on professional competence in HRM, we expect that many of the components of the model and program are generalizable to other management specialties. This review suggests that the following specific elements of competencies are of direct significance for effectiveness in the HR profession: 
- traits and motives (e.g., conscientiousness, adaptability, proactivity);

- functional HR knowledge (e.g., staffing, appraisal, compensation, employee relations);

- functional business knowledge (e.g., accounting, finance, marketing, operations);

- knowledge and skill in key organizational processes (e.g., change management, facilitation, and OD; leadership; interpersonal, coaching, and team skills; HR research and organization feedback); and

- knowledge of strategic HR management (e.g., linking HR to business strategy, consulting with executives, seeing and implementing a big picture perspective).

Traditional approaches to HR education deal primarily with the second bulleted point. A competency approach to the HR curriculum should address all five. In the next section, we describe an exploratory field study conducted at Reliant Energy by one of the authors. Together with the previously described literature, this field study contributed directly to the development of the competence-based master's degree program in HRM that has been implemented at one Western university.

\section{Field Study at Reliant Energy}

The study of HR competencies at Reliant Energy began in 1995 as a part of an overall effort to better align human resources with business strategy. After considerable research, benchmarking visits with companies that had developed HR competency models, and visits with consultants specializing in competency development, Reliant Energy developed an HR competency that combined the work of Dalton and Thompson (1986) on career stages with current work on HR competencies. The result was a dynamic competency model that explicitly acknowledges the evolution of competence across the career lifespan. This model reflects the observation that the demonstration of HR competence in a particular area changes as one gains experience, skill, and increasing responsibilities. Table 1 presents the four competency stages identified by this field study.

The final competence framework derived from observations during the field study consists of four categories: general business knowledge, organizational competence, HR technical competence, and professional credibility. Each of these categories includes a list of specific competencies. For example, general business competencies include financial, business unit, and strategic knowledge, whereas organizational competencies include teamwork, communication, project management, consulting, and change skills. Furthermore, each specific competency is observed and described in terms of specific work behavior. The final outcome of the field study at Reliant Energy 
TABLE 1

Stages of HR Competency ${ }^{\mathrm{a}}$

\begin{tabular}{|c|c|c|c|c|}
\hline \multirow{2}{*}{$\begin{array}{l}\text { HR Competency } \\
\text { Behavioral } \\
\text { Indicator } \\
\text { Categories }\end{array}$} & \multicolumn{4}{|c|}{ Competency Stages } \\
\hline & Acquiring & Applying & Mastering & Influencing \\
\hline $\begin{array}{l}\text { Categories of } \\
\text { behaviors } \\
\text { expected from } \\
\text { HR professionals } \\
\text { that lead to } \\
\text { successful } \\
\text { performance } \\
\text { of tasks and } \\
\text { responsibilities }\end{array}$ & $\begin{array}{l}\text { - Works under } \\
\text { the supervision } \\
\text { and direction of } \\
\text { a more senior } \\
\text { professional on } \\
\text { a portion of a } \\
\text { larger project or } \\
\text { activity doing } \\
\text { most of the } \\
\text { detailed and } \\
\text { routine work in } \\
\text { the project } \\
\text { using directed } \\
\text { creativity and } \\
\text { initiative } \\
\text { Learns to } \\
\text { perform well } \\
\text { under pressure } \\
\text { and accomplish } \\
\text { a task within the } \\
\text { time budgeted }\end{array}$ & $\begin{array}{l}\text { - Goes into depth } \\
\text { in one problem } \\
\text { or technical area } \\
\text { or a definable } \\
\text { portion of a } \\
\text { project, process } \\
\text { or clients, } \\
\text { relying less on } \\
\text { supervision or } \\
\text { mentor to solve } \\
\text { problems using } \\
\text { own resources } \\
\text { Independently } \\
\text { produces } \\
\text { significant } \\
\text { results } \\
\text { Develops } \\
\text { credibility and } \\
\text { a reputation }\end{array}$ & $\begin{array}{l}\text { Makes } \\
\text { significant } \\
\text { technical } \\
\text { contribution and } \\
\text { begins working } \\
\text { in more than one } \\
\text { area with greater } \\
\text { breadth and } \\
\text { application of } \\
\text { skills } \\
\text { Develops } \\
\text { younger } \\
\text { professionals } \\
\text { and assumes } \\
\text { formal and } \\
\text { informal } \\
\text { leadership } \\
\text { Deals with } \\
\text { clients and } \\
\text { customers } \\
\text { developing new } \\
\text { business and } \\
\text { so forth }\end{array}$ & $\begin{array}{l}\text { - Exercises formal } \\
\text { and informal } \\
\text { power to } \\
\text { initiate actions, } \\
\text { influence } \\
\text { e decisions, and } \\
\text { obtain resources } \\
\text { and approvals } \\
\text { - Represents the } \\
\text { organization to } \\
\text { individuals, } \\
\text { groups, and } \\
\text { institutions } \\
\text { inside and } \\
\text { outside the } \\
\text { organization } \\
\text { - Sponsors } \\
\text { promising } \\
\text { individuals to } \\
\text { test and prepare } \\
\text { them for key } \\
\text { roles in the } \\
\text { organization }\end{array}$ \\
\hline
\end{tabular}

NOTE: HR = human resources.

a. The four stages are from Dalton and Thompson (1986).

was a list of specific competencies for each category, described in behavioral terms consistent with the four-stage career-based model. Table 2 contains excerpts from the model that were derived from this field study.

The Reliant Energy model of HR competencies has three important characteristics. First, it assumes that the skilled behavior of HR professionals reflects underlying configurations of knowledge, skills, motives, and traits. Second, this model acknowledges that HR knowledge and competence evolve throughout one's career. Third, the dimensions inductively generated in the development of this model are highly consistent with those identified in prior research. We discuss each of these issues in greater detail before describing the implications of this model for curriculum design. 
The first important point, which must be considered from the perspectives of communicating program goals, as well as measurement of program effectiveness, is that the knowledge, skills, motives, and traits can be inferred only through observation of behaviors. Therefore, the model defines each competency in terms of specific behavioral examples (see Table 2).

The second issue, and a significant contribution of the field study, is the integration of a temporal, or developmental, dimension. Building on the work of Dalton and Thompson (1986), the model explicitly acknowledges that successful HR professionals will continue to develop as they increase their experience, knowledge, and skills. This is consistent with the argument that HR programs should attempt to provide a broad foundation on which professionals can build through their work experience and continuing professional development activities (Barber, 1999). In the present model, this developmental aspect is incorporated by including four distinct levels of competence: acquiring, applying, mastering, and influencing.

Each of the four stages coincides with stages of professional development. For example, on completion of an undergraduate degree with a focus or major in HRM, we would expect an individual to exhibit competencies at the acquiring level. Graduates of a master's program in HRM are expected to exhibit the applying level of competence in most areas (e.g., going into depth in a problem or technical area, working independently, being self-reliant in terms of problem solving, etc; see Table 1). Beyond the level of master's education, continued development of experience and knowledge leads to acquisition of a mastering level of competence and, for the most successful HR professionals who are able to gain access to senior organizational positions, the influencing level is expected to be acquired. This implies that a master's level curriculum should focus primarily on the first two levels: acquiring and applying.

The third significant feature in the competency model is its congruence with previous research on the competencies required to succeed as an HR professional. The four categories of competence, derived from field research at Reliant Energy (Table 2), are consistent with similar studies of competencies in HRM conducted during the last decade (e.g., Baill, 1999; Brockbank et al., 1999; Ulrich et al., 1995). For example, the studies by Ulrich and colleagues (1995) highlighted business knowledge, change agent (organizational) skills, technical HR competencies, and professional credibility. Kaufman (1999) noted that employers are seeking competencies such as communications and negotiating skills, as well as the general business knowledge such as the strategic implications of HRM.

Also consistent with prior research is the fact that this model is designed around the notion that competencies are multidimensional and reflect config- 
TABLE 2

Example HR Competency Behavioral Indicators

\begin{tabular}{|c|c|c|c|c|}
\hline $\begin{array}{l}\text { Competency } \\
\text { Category }\end{array}$ & Acquiring & Applying & Mastering & Influencing \\
\hline $\begin{array}{l}\text { General business } \\
\text { competence } \\
\text { (e.g., financial) }\end{array}$ & $\begin{array}{l}\text { Develops a } \\
\text { broad business } \\
\text { and financial } \\
\text { perspective }\end{array}$ & $\begin{array}{l}\text { Uses a broad } \\
\text { business and } \\
\text { financial } \\
\text { perspective }\end{array}$ & $\begin{array}{l}\text { Increases the } \\
\text { business and } \\
\text { financial } \\
\text { perspective } \\
\text { of others }\end{array}$ & $\begin{array}{l}\text { Partners with } \\
\text { HR council and/or } \\
\text { strategic business } \\
\text { unit leadership to } \\
\text { shape financial } \\
\text { decisions }\end{array}$ \\
\hline $\begin{array}{l}\text { Organizational } \\
\text { competence } \\
\text { (e.g., change } \\
\text { management) }\end{array}$ & $\begin{array}{l}\text { Understands } \\
\text { change } \\
\text { management } \\
\text { processes }\end{array}$ & $\begin{array}{l}\text { Diagnoses and } \\
\text { acts on } \\
\text { opportunities } \\
\text { for change }\end{array}$ & $\begin{array}{l}\text { Partners with } \\
\text { others to } \\
\text { develop a vision } \\
\text { for change; } \\
\text { effectively } \\
\text { navigates power } \\
\text { structures }\end{array}$ & $\begin{array}{l}\text { Inspires and } \\
\text { motivates others } \\
\text { to sponsor } \\
\text { cultural change }\end{array}$ \\
\hline $\begin{array}{l}\text { HR technical } \\
\text { competence } \\
\text { (e.g., compensa- } \\
\text { tion-base pay } \\
\text { design and } \\
\text { delivery) }\end{array}$ & $\begin{array}{l}\text { Develops } \\
\text { knowledge of } \\
\text { pay design and } \\
\text { delivery plan } \\
\text { technical issues }\end{array}$ & $\begin{array}{l}\text { Demonstrates } \\
\text { the ability to } \\
\text { diagnose and } \\
\text { solve typical } \\
\text { design problems } \\
\text { and is perceived } \\
\text { as knowledge- } \\
\text { able in the } \\
\text { fundamentals }\end{array}$ & $\begin{array}{l}\text { Develops and } \\
\text { implements } \\
\text { effective } \\
\text { solutions to } \\
\text { complex design } \\
\text { issues consis- } \\
\text { tently and is } \\
\text { recognized as } \\
\text { business focused } \\
\text { with a deep } \\
\text { understanding } \\
\text { of technical } \\
\text { concepts and } \\
\text { issues }\end{array}$ & $\begin{array}{l}\text { Partners with } \\
\text { management in } \\
\text { shaping design } \\
\text { solutions that } \\
\text { support benefit } \\
\text { strategy, total } \\
\text { reward strategy, } \\
\text { business strategy, } \\
\text { and corporate } \\
\text { values }\end{array}$ \\
\hline $\begin{array}{l}\text { Professional } \\
\text { credibility } \\
\text { (e.g., building } \\
\text { relationships } \\
\text { and trust) }\end{array}$ & $\begin{array}{l}\text { Builds supportive } \\
\text { team ties and } \\
\text { relationships }\end{array}$ & $\begin{array}{l}\text { Partners with } \\
\text { others to deliver } \\
\text { products }\end{array}$ & $\begin{array}{l}\text { Is sought out for } \\
\text { knowledge and } \\
\text { mentoring } \\
\text { abilities }\end{array}$ & $\begin{array}{l}\text { Coaches and } \\
\text { influences } \\
\text { leaders }\end{array}$ \\
\hline
\end{tabular}

NOTE: HR = human resources

urations of skills, knowledge, traits, and motives (Mansfield, 1996; Schoonover, 1998). These characteristics are central to the challenges surrounding the design of a competency-based curriculum. The next section describes how this competence-based model is integrated into the HRM graduate curriculum at one university. Following this description, we outline 
the key challenges that must be addressed when seeking to implement this evolution in an educational program.

\section{Designing a Competency-Based Curriculum}

The curriculum redesign for the master's degree in HRM at this university draws directly on the research described above. Important assumptions of this process are that traits and motives form a relatively stable foundation for competencies and that a graduate program provides an opportunity for students to acquire the critical knowledge and skills. Another assumption is that an effective competence-based education should allow students to model and practice the behaviors that reflect the critical professional competencies.

The first stage in curriculum development involved identification of the various components of professional competence (i.e., the specific traits, skills, and knowledge elements). This process built on the literature reviewed above, the results of the field study, and many formal and informal discussions with HR practitioners and executives during the past several years (e.g., Scarpello, 2002). The result was a list of traits, motives, skills, and knowledge that are expected to be associated with professional competence.

The traits and motives identified as critical to success in an HR career were adaptability (i.e., flexibility, openness to new ideas), proactivity (i.e., initiative and resourcefulness, being a self-starter), respect (i.e., respect for people and alternative viewpoints), conscientiousness (i.e., preparation, follow through, results orientation), quick study (i.e., able to become knowledgeable quickly), courage (i.e., willingness to stand up for correct principles), integrity (i.e., honesty, trustworthiness), energy level, (i.e., enthusiasm, activity level), and self-esteem (i.e., self-worth, confidence).

Four categories of skills were identified: cognitive skills, communication skills, collaborative skills, and consulting skills. Cognitive skills include critical and analytical thinking, strategic thinking, global thinking, and thinking on one's feet. Skills in communication include oral communication, formal presentation, and written communication (including executive summary format). Collaborative skills include interpersonal and group process skills, listening and supportive communication, giving and receiving feedback, negotiation and conflict management, group facilitation, group problem solving, and team skills. Consulting skills include psychological contracting, problem identification, action research, change management, measurement and evaluation, and goal setting and action planning.

Consistent with most HR graduate programs across the country (Way, 2002), knowledge to be imparted includes the following areas: general busi- 


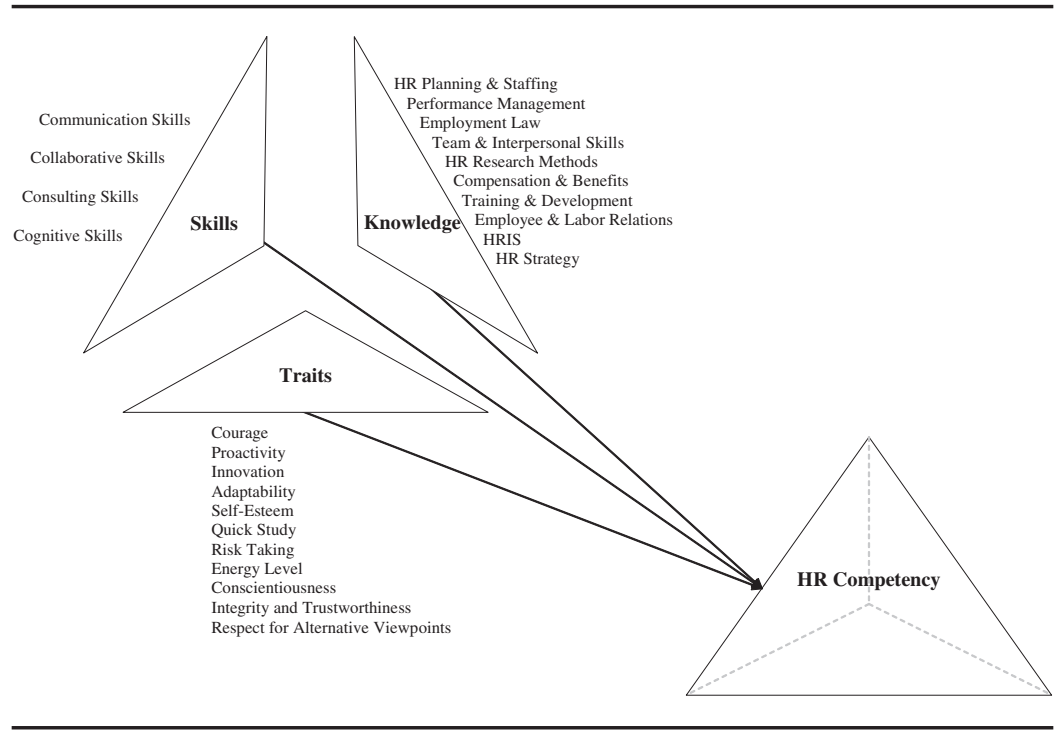

Figure 1: HR Competencies

$\mathrm{HR}=$ human resources; HRIS $=$ human resource information systems.

ness knowledge (i.e., finance, accounting, marketing, economics, operations, statistics), employment law, organizational behavior, HR planning and staffing, performance management, compensation and benefits, employee and labor relations, human resource information systems and human capital management, training and organization development, applied HR research, and HR strategy and policy. As noted above, skill and knowledge development was designed to meet the applying level (Stage 2) of the Reliant Energy model in most cases. The overall model on which the curriculum is based is summarized in Figure 1.

As Figure 1 suggests, the competency model draws on configurations of traits, knowledge, and skills. It is assumed that traits are largely nonmalleable in the context of a 1- or 2-year graduate program. However, it is possible to integrate awareness of traits into the program through self-assessment and developmental exercises, thereby promoting a complete approach to professional competence. Therefore, one goal of the program is to develop selfawareness through self-assessment using paper-and-pencil instruments (e.g., the Jackson Personality Inventory). The program is designed to highlight the traits that have been identified in empirical research as being important to professional competence. A key part of the program involves self-assessment of personal strengths and weaknesses with respect to these traits. Thus, 
although we do not seek to directly transform personality characteristics, the development of greater self-knowledge by students helps them to play to their strengths and work around their weaknesses when building and using skills and knowledge to achieve professional competence.

Students are taught the technical HRM knowledge through the traditional functionally based class structure. However, building across the knowledge areas, and therefore across all classes, the program emphasizes the four key skill sets: consulting, collaboration, communication, and cognitive skills. These skill sets are evaluated throughout the program using a common set of behaviorally based measures, thus reinforcing their significance and allowing students and faculty to monitor strengths, weaknesses, and improvements during the course of the program. The adoption of this model required changes to the curriculum in three key areas: student orientation, student development, and student assessment.

\section{STUDENT ORIENTATION}

An extensive new student orientation was developed to assist students in getting a clear understanding of the program expectations, the HR competency model, and differences between an undergraduate and graduate education. In addition, it allows for informal interaction between the faculty and students facilitating open and informal communications and the formation of mentoring relationships.

The orientation is held at an offsite outdoor learning center prior to the start of classes. The agenda includes several ice breaker activities as well as the completion of self-assessments of the skill- and trait-related aspects of HR competencies. This represents the first opportunity for students to learn about the components of the competency model and, more specifically, the traits, knowledge, and skills that they would be expected to develop or enhance during the course of their careers as HR professionals.

Two self-assessment instruments were designed to both communicate the nature of the desired traits and skills and help students establish a baseline of where they stand entering the program. The first of these instruments is a skills inventory, adapted from the Hellreigel, Jackson, and Slocum's (2002) Management Skills Inventory. This measure lists 55 skill descriptions and uses a Likert-type 5-point scale. The 55 items were designed to reflect 10 subdimensions of the four primary skill sets: cognitive skills, collaborative skills, consulting skills, and communication skills. The participants are provided with summary scores for each of 10 subdimensions for themselves and the mean for their peer group. 
The second instrument is a measure of the 11 key traits identified in the literature review as being related to success in the HR profession: proactivity, adaptability, conscientiousness, self-esteem, integrity, quick study, risk taking, courage, energy level, respect for the opinions of others, and innovativeness. The individual items were derived from a range of established measures including the Jackson Personality Inventory (innovativeness, risk taking, energy level); Rokeach's (1960) Dogmatism Scale (respect for the opinions of others); Goldberg's (1999) scale of the Big Five personality constructs (conscientiousness); Cloninger, Przybeck, Svrakic, and Wetzel's (1994) Temperament and Character Inventory (conscientiousness); Jackson, Paunonen, and Tremblay's (2000) Six Factor Personality Scale (Adaptability); the Rosenberg Self-Esteem Scale (Crandal, 1973); and Hofstee, de Raad, and Goldberg's (1992) Abridged Big Five Dimensional Circumplex Model (quick study). The students were each provided with a description of the meaning of each dimension, their mean score on each dimension, and the means for their peer group.

The self-assessment and feedback process served to introduce the broader teaching philosophy on which we have built the master's program and to provide a baseline by which students could evaluate their progress as they proceeded through the program. In addition to this process, a significant amount of time was dedicated to indoor and outdoor experiential exercises, which were facilitated by the faculty and intended to demonstrate important competencies in action. As part of this orientation, three recent graduates were invited to host an informal panel discussion. Each panel member gave a short summary of his or her graduate and professional experience and then answered questions posted by the new students. This was also used as an opportunity to highlight important competencies and reinforce their significance for success after graduation.

\section{STUDENT DEVELOPMENT}

The developmental component of the competence-based curriculum has several key features. First, a skill-based pedagogy is employed to supplement the more traditional knowledge-based pedagogy. The revised curriculum using a competency development format takes a broad approach using projectbased and experiential learning models within courses to develop these competencies. This allows students to learn by doing and to develop and practice the skills necessary to be an effective HR professional. For example, in the performance management and research methods courses, a primary focus is an applied project in which students work with a client organization to analyze their existing performance appraisal system, collect and analyze user 
reactions to the system, and present recommendations for improvement to the organization's leadership. In these projects, students operate in real-time and real-life contexts, employing both the knowledge and critical skills of the HR competency model.

The second and perhaps more distinctive feature of this competencebased curriculum from a developmental perspective is that ongoing skills assessments, using criteria agreed on by all faculty, are employed consistently and across all classes. For example, in the integrative projects described above, students are evaluated on their consulting skills and communication skills, as well as on the knowledge specific to each course. This has several effects. First, it creates a more holistic graduate education for the students as the assessment ties together the knowledge and skills across what are traditionally more discrete educational experiences within a program of study. Second, the multiple assessments provide a more reliable and valid indicator of the effectiveness of the curriculum in developing critical skills in addition to the usual assessment of knowledge acquisition. Third, the consistent assessment across courses keeps the focus of the individual courses tethered to the core HR competencies. In this way, we suggest that this competence-based curriculum incorporates the much needed integration and coherency across the courses and thereby enhances both rigor and relevance (Pfeffer \& Fong, 2002).

\section{STUDENT ASSESSMENT}

Given the desire to emphasize competence over simple knowledge acquisition, it becomes clear that traditional methods of evaluation are insufficient to fully assess a student's progress through the program. Therefore, in addition to traditional course grades and the cross-course standardized assessments of skill sets such as communications and consulting, students engage in an assessment and feedback process at 10-week intervals throughout the program. (Note that the university in this case is on a 15 -week semester, so these 10-week reviews do not conflict with end-of-semester exams, papers, or projects.) These workshops take the form of miniassessment centers in which multiple assessment activities take place.

During the workshop, students engage in various activities designed to allow them to demonstrate the various HR competencies. All of these activities are observed by faculty with certain activities also being videotaped. These activities include a leaderless group discussion, an in-basket exercise, HR case analyses, and a brief standup presentation. The videotaped activities are used in two ways. First, shortly following the activity, the students watch the video and discuss what they observe in their own behavior and that of 
their peers. Second, the video is observed again at a later review (e.g., 10 or 20 weeks later). This is typically done after the students have done a similar assessment, which allows them to observe changes and progress in their behavior and competencies over time.

During these half-day workshops, students also receive feedback both from faculty and peers. Peer feedback is completed anonymously before the workshop, using a Behaviorally Anchored Rating Scale that focuses on the key skill sets that contribute to the competencies in the model. Faculty feedback is compiled by a faculty panel that exchanges behavioral observations of the students with respect to the HR competencies. The faculty comments are summarized by a faculty mentor, who discusses the feedback one-on-one with the student during the workshop. The faculty also provides feedback and observations from the workshop activities. Each student also has the opportunity to discuss the feedback from their peers with the faculty member. Finally, the students have the opportunity to discuss all the feedback with a peer to seek clarification as well as advice for improvement. To help ensure the feedback is put to use, at the conclusion of the workshop, students are given the charge to incorporate the feedback received into a personal development plan that includes specific goals for improving in three competency areas and the steps they will take to meet the goals. These plans are subsequently reviewed with their faculty mentor. This process helps reinforce to program participants the importance of the skill sets that they are continually developing throughout their graduate education. The process also helps faculty maintain a focus on the big picture-developing effective HR professionals.

Each year, the graduating students participate in an exit interview designed to assess the impact of the program in terms of student satisfaction with the rigor and relevance of the curriculum. Of the small sample of interviews so far conducted, students rated the relevance of the curriculum to be a 6.7 on a 7-point scale. In particular some comments were as follows: "[There is] really good material and what is needed to be a good professional"; "I feel well prepared to enter the workforce"; "[I learned] practical information that will be needed to work in HR"; "I learned how to learn material on my own." When asked about the rigor and mental stimulation of the curriculum, the response was 6.8 on a 7-point scale. Comments included the following: "There was way more material to learn than I originally thought"; "I thought I had good analytical skills before; now I know they were weak"; "[The curriculum] pushed me to think, analyze, and make conclusions"; "I really developed my critical-thinking and decision-making skills." When asked, "what overall grade would you give the program?" the score received from the first graduating cohort was a grade of 3.9 (out of 4.0), or A. Comments included 
the following: "good program, good opportunity"; "I liked the close feeling between students and faculty"; "Faculty were accessible." Future assessment of the program will include a quantitative evaluation of the link between competence development in the program and performance criteria such as GPA, number of job offers, and first salary on graduation.

\section{Looking Forward: Challenges Remaining and Future Steps}

The competence-based curriculum described here continues to be developed and refined as the faculty learn by doing and as feedback is collected from past and present students in the program. One issue that has yet to be addressed relates to the role of traits and motives that are believed to contribute to HR competencies (Brockbank et al., 1999). We have suggested that traits form an important foundation of the configurations of knowledge, skills, abilities, and other characteristics that comprise competencies. However, it is also generally accepted that traits tend to be quite stable over time and resistant to change. The strategy adopted to date in the implementation of the curriculum is to direct students' attention to the importance of traits and to

offer feedback on their own personal characteristics using well-established measures of those personality characteristics. A second strategy is also possible, although its utility remains to be established: selection of students for the program, based on the presence of competency-related traits.

This selection strategy raises more questions than we have managed to answer to date. First, are the traits identified by our research predictive of long-run success for HR professionals? There is evidence that leads us to expect that traits are important to success, although the efficacy of specific personality dimensions as predictors of work performance has been somewhat limited to date (Barrick \& Mount, 1991). Second, what is the appropriate criterion in this case? Is it long-term career success or immediate postgraduation performance? Furthermore, do the same traits predict success for different HR roles such as employee advocate versus change agent or strategic partner (Ulrich, 1997) or different positions such as compensation analyst versus employee relations officer? Identification of a criterion is highly problematic when trying to assess so-called professional competence. Third, do trait measures have incremental validity beyond knowledge and skills and, in particular, beyond traditional indicators of scholastic aptitude such as the Graduate Management Admissions Test? Fourth, what is the base rate of these characteristics in the population? Are they indeed scarce characteristics, or are they broadly present, at least among applicants for graduate 
education in HR? Does self-selection into the applicant pool restrict the range of traits exhibited by entering students? The utility of selecting potential program participants based on traits will be limited if they are either very scarce or very widespread. Fifth, all of the foregoing assumes an HR graduate program that is able to be selective in terms of the students admitted beyond looking at GPA and GMAT scores. Unless the selection rate is relatively small, the utility of adding new hurdles to entry beyond GPA and GMAT scores can be expected to be negligible.

A second issue that we have addressed in the development of our model is the extent to which a skills-based or competency-based approach such as ours is limiting rather than liberating. Asking students to demonstrate specific knowledge and skills may perhaps produce students who do not think for themselves or who do not do the courageous things that HR professionals are occasionally required to do (e.g., confronting a powerful upper-level manager about sexual harassment allegations or encouraging the whistleblower who is aware of accounting irregularities). However, we believe that the HR competencies we have identified are sufficiently robust to allow us to produce students who are both able to function effectively in a professional HR role and able to take the risks necessary from time to time to change the organization from the inside out. When change is needed, students from this program will be competent in such areas as negotiation, organization development, consulting and counseling, team and interpersonal dynamics, psychological contracting, group facilitation, action research, and so forth. However, the proper balance of emphasis between these change and action skills versus the more traditional knowledge areas (e.g., compensation, selection) is a topic of ongoing investigation. Ultimately, we will need to assess the degree of success of our graduates and identify to what extent their success is a function of the application of knowledge or the use of change and action skills.

A third set of challenges that results from this competence-based curriculum relates to practical concerns of both faculty and the institution itself. First, as is apparent, the implementation of this curriculum adds significant task requirements for teaching faculty. Some parts of this additional load, such as redesigning individual courses around the integrated model and designing the workshop content, may be considered fixed costs that once spent will return infrequently. Other parts of the new load are inherently variable, in particular the commitment of faculty time to both orientation and ongoing student development and assessment. As program size increases, so will the faculty time that is needed to manage these processes. Participating faculty note that collaboration and synergy are essential components of a competency-based model. Said one faculty member, 
Since the competency model is used across all courses with our graduate students, it would not have been possible to implement the model with any impact unless it was a collaborative effort from all of the professors involved. As a result of that collaboration, we not only emerged with combined commitment to implement it, but it also resulted in a much richer and refined model as a result of the collaborative effort. This was an undertaking that required the best of our thinking over a sustained period, and we continue to refine it as we gain experience.

Although faculty members agree implementation of a cross-curricular competency-based model requires more work on their part, they also note several benefits, including greater unity among colleagues participating in the process and a greater sense of accomplishment in their work. These sentiments are reflected in comments by faculty contributors. In the words of one faculty member, "it is definitely more work than just showing up and teaching your course-but also way more rewarding to see faculty working together toward a common compelling objective." Another reflected, "the process ensures that faculty spend more than the usual amount of time interacting. This means a higher level of involvement and I think it helps to bind us together." A third faculty member reflected,

there is no question that such an undertaking as this requires significant effort beyond the normal teaching and research workload. However, the return in the positive impact on graduate students, the impact on my own attitude and focus, and the collective commitment we feel to our students and the process of helping them prepare for a promising career and life far outweigh the investment.

Capping off these insights, one faculty member reflected, "it's the way I always felt the educational system should function, and I find it energizing to be a part of it."

Beyond these challenging issues, the early feedback from the new competencebased graduate program is positive. Both students and faculty have found that the early orientation program and ongoing feedback have enhanced the teacher-student relationship. According to student feedback, at least three benefits have been identified. First, students are becoming keenly aware of the importance of competencies and of the knowledge, skills, abilities, and other characteristics that form those competencies. Second, students are also aware of the faculty's commitment to their future professional success. Third, the process helps strengthen a collaborative and trusting relationship between faculty and students, which we believe enhances the performance and satisfaction of all involved. The following vignette provided by a faculty member supports this finding. 
One positive outcome I've observed is the clarity of purpose that the students gain from the competency model. It answers the question, "What am I supposed to get out of this?" For example, [one day] in class we were discussing a potential change to class administration, and one of the students asked which course of action would best move them forward on the HR competencies. I found this comment very rewarding because it means the student is focusing on maximizing what competencies they gain from the program and not on maximizing ease or grades.

Finally, although the focus of the present article has been the application of competency-based education in the preparation of HRM professionals, it is becoming increasingly clear that the model holds promise for other management disciplines as well. This project is still in its earliest stages, and future research needs to focus on assessing program effectiveness and on empirically validating the competence-based model proposed here. However, based on experience to date, the competence-based approach to curriculum design holds promise for meeting recent challenges regarding the rigor and relevance of management education.

\section{References}

Baill, B. (1999). The changing requirements of the HR professional: Implications for the development of HR professionals. Human Resource Management, 38, 171-176.

Barber, A. B. (1999). Implications for the design of human resource management education: Education, training, and certification. Human Resource Management, 38, 177-182.

Barrick, M. R., \& Mount, M. K. (1991). The Big Five personality dimensions and job performance: A meta-analysis. Personnel Psychology, 44, 1-26.

Boyatzis, R. E., Stubbs, E. C., \& Taylor, S. N. (2002). Learning cognitive and emotional intelligence competencies through graduate management education. Academy of Management Learning and Education, 2, 150-162.

Brockbank, W., Ulrich, D., \& Beatty, R. W. (1999). HR professional development: Creating the future creators at the University of Michigan Business School. Human Resource Management, 38, 111-118.

Campbell, J. P. (1990). Modeling the performance prediction problem in industrial and organizational psychology. In M. D. Dunnette \& L. M. Hough (Eds.), Handbook of industrial and organizational psychology (2 ed., Vol. 1, pp. 687-732). Palo Alto, CA,: Consulting Psychologists.

Cloninger, C. R., Przybeck, T. R., Svrakic, D. M., \& Wetzel, R. D. (1994). The Temperament and Character Inventory (TCI): A guide to its development and use. St. Louis, MO: Center for Psychobiology of Personality, Washington University.

Crandal, R. (1973). The measurement of self-esteem and related constructs. In J. P. Robinson \& P. R. Shaver (Eds.), Measures of social psychological attitudes (Rev. ed., pp. 80-82). Ann Arbor, MI: Institute for Social Research.

Dalton, G. W., \& Thompson, P. H. (1986). Novations: Strategies for career management. Glenview, IL: Scott, Foresman. 
Goldberg, L. R. (1999). A broad-bandwidth, public-domain, personality inventory measuring the lower-level facets of several five-factor models. In I. Mervielde, I. Deary, F. De Fruyt, \& F. Ostendorf (Eds.), Personality psychology in Europe (Vol. 7, pp. 7-28). Tilburg, The Netherlands: Tilburg University Press.

Hellreigel, D., Jackson, S. E., \& Slocum, J. W. (2002). Management: A competency-based approach (9th ed.). Cincinnati, OH: Southwestern.

Heneman, R. L. (1999). Emphasizing analytical skills in HR graduate education: The Ohio State University MLHR program. Human Resource Management, 38, 131-134.

Hofstee, W. K. B., de Raad, B., \& Goldberg, L. R. (1992). Integration of the Big Five and circumplex approaches to trait structure. Journal of Personality and Social Psychology, 63, 146-163.

Jackson, D. N., Paunonen, S. V., \& Tremblay, P. F. (2000). Six factor personality questionnaire manual. Port Huron, MI: Sigma Assessment Systems.

Kaufman, B. E. (1999). Evolution and current status of university HR programs. Human Resource Management, 38, 103-110.

Kochanski, J. T., \& Ruse, D. H. (1996). Designing a competency-based human resources organization. Human Resource Management, 35, 19-34.

Lawson, T. E., \& Limbrick, V. (1996). Critical competencies and developmental experiences for top HR executives. Human Resource Management, 35, 67-86.

Mansfield, R. S. (1996). Building competency models: Approaches for HR professionals. Human Resource Management, 35, 7-18.

McClelland, D. C. (1973). Testing for competence rather than intelligence. American Psychologist, 28, 1-14.

Pfeffer, J., \& Fong, C. T. (2002). The end of business schools? Less success than meets the eye. Academy of Management Learning and Education, 1, 78-95.

Rokeach, M. (1960). The open and closed mind. New York: Basic Books.

Scarpello, V. G. (2002, August). HR education: Is it dead or just sleeping? Paper presented at the Academy of Management Annual Meeting, Denver, CO.

Schoonover, S. C. (1998). Human resource competencies for the year 2000. Alexandria, VA: Society for Human Resource Management.

Spencer, L. M., Jr., \& Spencer, S. M. (1993). Competency at work: Models for superior performance. New York: John Wiley.

Ulrich, D. (1997). Human resource champions. Boston: Harvard Business School Press.

Ulrich, D., Brockbank, W., Yeung, A. K., \& Lake, D. G. (1995). Human resource competencies: An empirical assessment. Human Resource Management, 34, 473-495.

Way, P. K. (2002, November). The HR/IR practice-curriculum gap: Extent, causes, and responses. Paper presented at the Third Conference on Innovative Teaching in Human Resources and Industrial Relations, The Ohio State University, Cincinnati, $\mathrm{OH}$. 